\title{
KARAKTERISTIK FISIK TEPUNG KACANG KORO PEDANG (Canavalia ensiformis L.) DENGAN PERENDAMAN pH YANG BERBEDA
}

\section{Physical Characteristic of Flour Seed Koro Pedang Bean (Canavalia ensiformis L.) with Different $\mathrm{pH}$ Immersion}

\author{
Arba'ani les Wahyaningtiyas*, Yoga Pratama, Bhakti Etza Setiani \\ 1Jurusan Pertanian, FPP Universitas Diponegoro Jl. Prof. Soedarto Semarang 50275 \\ *Penulis Korespondensi, email : aya.4feb@gmail.com
}

\begin{abstract}
ABSTRAK
Penelitian ini bertujuan untuk mengetahui rendemen dan karakteristik fisik yang meliputi nilai kecerahan, aktivitas air $\left(a_{w}\right)$ dan densitas kamba fraksi tepung kacang koro pedang dengan perlakuan perendaman $\mathrm{pH}$ yang berbeda. Materi yang digunakan adalah biji kacang koro pedang yang diperoleh dari UKM Damar Sindoro Sumbing, Kecamatan Kandangan, Kabupaten Temanggung, Jawa Tengah. Biji kacang koro pedang direndam pada $\mathrm{pH}$ 4, 5, 6 dan 7 (kontrol) selama 24 jam. Biji yang telah direndam kemudian dikupas, dibuat bubur koro, dipisahkan fraksi-fraksinya dan dioven dengan suhu $45{ }^{\circ} \mathrm{C}$ selama 24 jam lalu ditepungkan dan dianalisa hasil rendemen, nilai kecerahan, aktivitas air $\left(\mathrm{a}_{\mathrm{w}}\right)$ dan densitas kamba. Penelitian menggunakan metode Rancangan Acak Lengkap (RAL) dilakukan sebanyak 5 kali pengulangan. Data hasil analisa yang diperoleh, ditabulasi dengan ANOVA pada taraf signifikansi $5 \%$. Hasil penelitian menunjukkan pengkondisian $\mathrm{pH}$ berpengaruh terhadap kecerahan, nilai $a_{w}$ dan densitas kamba beberapa fraksi tepung kacang koro pedang, tetapi tidak memberikan pengaruh terhadap nilai rendemen. Secara keseluruhan perlakuan perendaman $\mathrm{pH}$ biji kacang koro pedang tidak menunjukkan pengaruh yang nyata (signifikan) terhadap fraksi-fraksi tepung secara jumlah tetapi diduga dapat meningkatkan karakter molekul di dalamnya. Perlakuan terbaik dari hasil penelitian adalah dengan perendaman $\mathrm{pH}$ 7 karena memiliki nilai rendemen tinggi, meskipun kecerahan dan densitas kamba rendah, karena perlakuan $\mathrm{pH} 7$ tidak mempengaruhi karakteristik fisik hasil tepung kacang koro pedang dan tidak menimbulkan efek residu terhadap hasil akhir karena tidak adanya penambahan asam pada saat perendaman bahan.
\end{abstract}

Kata Kunci: densitas kamba, kecerahan, perendaman $\mathrm{pH}$, rendemen, tepung koro pedang.

\section{ABSTRACT}

This research aims to determine of yield and physical characteristics that include the value of brightness, water activity $\left(a_{w}\right)$ and bulk density of flour seed koro pedang bean fraction with different of $\mathrm{pH}$ immersion treatment. The material used is flour seed koro pedang bean obtained from UKM Damar Sindoro Sumbing, Kandangan District, Temanggung Regency, Central Java. The seeds of koro pedang bean are soaked at pH 4, 5, 6 and 7 for 24 hours. Seeds that have been soaked and then peeled, made koro slurry, separated fractions and the oven with temperature $45{ }^{\circ} \mathrm{C}$ for 24 hours then milled and analyzed the results of yield, brightness value, water activity $\left(a_{w}\right)$ and bulk density. The research using Completely Randomized Design (CRD) method was done 5 times repetition. The data were analized by ANOVA at 5\% significance level. The results showed that $\mathrm{pH}$ conditioning had an effect on the brightness, aw value and bulk density of some flour seed koro pedang fraction, but didn't give effect to the value of yield. Overall, the treatment of soaking $\mathrm{pH}$ of koro pedang seed didn't show significant effect on the flour fractions in quantity and physically but possibility can be increase the molecular character.

Key Words: flour seed koro pedang bean, $\mathrm{pH}$ immersion, yield, brightness, bulk density. 


\title{
PENDAHULUAN
}

Indonesia merupakan salah satu negara yang kaya akan hasil pertaniannya. Salah satu jenis kacang-kacangan yang telah lama dikenal di Indonesia adalah kacang koro. Kacang koro pedang berpotensi untuk dijadikan substitusi pangan berbasis protein. Koro pedang juga berpotensi menjadi pangan fungsional. Hal ini dibuktikan pada penelitian Istiani (2010) bahwa dalam koro pedang putih terdapat komponen aktif flavonoid sebesar 29,3 mg/100 gram tepung biji dan total fenolnya sebesar $245,5 \mathrm{mg} / 100$ gram tepung biji serta memiliki aktivitas antioksidan pada koro pedang utuh yaitu $47,13 \%$ yang dapat menangkal radikal bebas yang bersifat merugikan bagi kesehatan. Koro pedang juga memiliki kandungan nutrisi lain yaitu vitamin B1 dan B2 (Gilang et al., 2013). Penelitian ini mengkaji pengaruh pengkondisian perendaman $\mathrm{pH}$ pada kondisi asam dan netral untuk menghasilkan tepung koro pedang dengan fraksi-fraksi yang berbeda yaitu fraksi serat, pati dan protein. Perendaman kacang koro pedang pada $\mathrm{pH}$ asam bertujuan untuk mengendapkan protein agar diperoleh tepung kacang koro pedang fraksi protein. $\mathrm{pH}$ isoelektrik muatan gugus amino dan karboksil bebas dalam molekul asam amino akan saling menetralkan, sehingga muatan molekul protein tersebut menjadi nol dan apabila dilakukan elektrolisis tidak akan terjadi perpindahan molekul protein. Setiap jenis protein memiliki titik isoelektrik pada $\mathrm{pH}$ tertentu dan pada $\mathrm{pH}$ tersebut protein akan mengendap dengan cepat (Poedjiadi, 1994).

Penelitian yang banyak dilakukan sebelumnya yaitu pembuatan tepung kacang koro pedang berprotein tinggi dengan proses pengkondisian $\mathrm{pH}$ dilakukan di akhir, tetapi pada penelitian ini adalah mengganti proses pengkondisian $\mathrm{pH}$ dengan metode pemisahan fisik yang dilakukan di awal proses dengan harapan dapat mengurangi jumlah residu yang dihasilkan dan dapat meningkatkan hasil rendemen serta beberapa karakteristik fisik lainnya.

\section{BAHAN DAN METODE}

\section{Bahan}

Materi yang digunakan adalah kacang koro pedang yang diperoleh langsung dari UKM Damar Sindoro Sumbing, Kecamatan Kandangan, Kabupaten Temanggung, aquades dan $\mathrm{HCl} 0,1 \mathrm{~N}$.

\begin{abstract}
Alat
Peralatan yang digunakan adalah blender merk Phillips, baskom, pengaduk, timbangan analitik merk Simadzu, pH meter merk Suncare tipe $\mathrm{PH}-009$, plastik wrap, sendok, kain saring, gelas ukur, gelas beker, pipet tetes, selang bening, bola hisap, refrigerator, sentrifuge merk Hettich, loyang, oven pengering merk Getra, $a_{w}$ meter merk Novasina, tube, cawan porselen, desikator, penjepit, plastik klip, digital kolorimeter merk Apple.

\section{Metode}

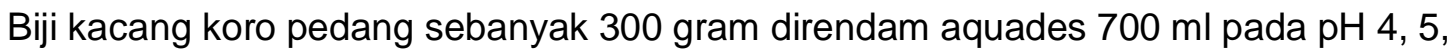
6 dan 7 (kontrol) selama 24 jam. Biji yang telah direndam kemudian dikupas, dibuat bubur koro, dipisahkan fraksi-fraksinya (serat, pati dan protein) kemudian dioven dengan suhu 45 ${ }^{\circ} \mathrm{C}$ selama 24 jam lalu ditepungkan dan dianalisa karakteristik fisik meliputi hasil rendemen (Indriyani dan Susanto, 2013), nilai kecerahan (Widayat, 2013), aktivitas air (Poernomo et al., 2004) dan densitas kamba (Indriyani et al., 2013). Data hasil analisa yang diperoleh, ditabulasi dengan ANOVA (Analysis of Variance) pada taraf signifikansi 5\%. Apabila terdapat pengaruh perlakuan, maka dilanjutkan dengan Uji Wilayah Ganda Duncan (Uji Duncan).
\end{abstract}




\section{HASIL DAN PEMBAHASAN}

\section{Rendemen}

Tabel 1. Rendemen Fraksi Tepung Kacang Koro Pedang dengan Perlakuan Perendaman $\mathrm{pH}$ yang Berbeda

\begin{tabular}{cccc}
\hline Perlakuan & Fraksi Serat $(\%)$ & Fraksi Pati $(\%)$ & Fraksi Protein $(\%)$ \\
\hline T1 & $35.12 \pm 2.964$ & $6.92 \pm 1.006$ & $10.77 \pm 2.097$ \\
T2 & $36.09 \pm 1.479$ & $7.23 \pm 1.139$ & $11.63 \pm 0.719$ \\
T3 & $35.87 \pm 2.487$ & $6.09 \pm 2.071$ & $10.87 \pm 0.922$ \\
T4 & $37.28 \pm 1.784$ & $7.30 \pm 0.335$ & $12.01 \pm 1.179$ \\
\hline
\end{tabular}

Keterangan :

$\mathrm{T} 1=$ Fraksi Tepung Kacang Koro Pedang dengan Perlakuan Perendaman pH 4

T2 = Fraksi Tepung Kacang Koro Pedang dengan Perlakuan Perendaman pH 5

T3 = Fraksi Tepung Kacang Koro Pedang dengan Perlakuan Perendaman pH 6

$\mathrm{T} 4=$ Fraksi Tepung Kacang Koro Pedang dengan Perlakuan Perendaman $\mathrm{pH} 7$

Hasil uji nilai rendemen tepung kacang koro pedang tidak terdapat pengaruh perendaman $\mathrm{pH}$ terhadap hasil rendemen fraksi-fraksi tepung kacang koro pedang. Berdasarkan hasil perhitungan rendemen fraksi tepung kacang koro pedang diperoleh bahwa jumlah rendemen dengan rata-rata jumlah terbanyak terdapat pada fraksi tepung kacang koro pedang dengan perlakuan $\mathrm{pH} 7$ yaitu serat sebanyak $37.28 \%$, pati sebanyak $7.30 \%$ dan protein sebanyak $12.01 \%$. Data hasil akhir rendemen tersebut menunjukkan perlakuan terbaik untuk mendapatkan jumlah rendemen yang tinggi yaitu dengan perendaman $\mathrm{pH} 7$ (netral), selain itu pada perlakuan $\mathrm{pH} 7$ juga diperoleh jumlah rendemen protein yang tinggi sehingga diharapkan pula mampu meningkatkan kandungan protein di dalamnya.

Rendemen tepung kacang koro pedang dari ketiga fraksi serat, pati dan protein hanya menghasilkan sekitar $50 \%$ rendemen dari total bahan awal biji koro pedang karena adanya proses pemanasan dan pengupasan kulit biji yang tebal. Menurut Rizal et al. (2013) nilai rendemen yang rendah disebabkan penyusutan bobot akibat air yang hilang karena pemanasan. Winarno (2002) menambahkan, adanya proses pengeringan menyebabkan kandungan air dalam bahan pangan selama proses pengolahan berkurang sehingga mengakibatkan penurunan kadar rendemen suatu bahan.

\section{Kecerahan}

Tabel 2. Kecerahan Fraksi Tepung Kacang Koro Pedang dengan Perlakuan Perendaman $\mathrm{pH}$ yang Berbeda

\begin{tabular}{cccc}
\hline Perlakuan & Fraksi Serat $(\%)$ & Fraksi Pati $(\%)$ & Fraksi Protein $(\%)$ \\
\hline T1 & $70.20 \pm 0.124^{\mathrm{bc}}$ & $88.07 \pm 0.208^{\mathrm{a}}$ & $63.96 \pm 2.002$ \\
T2 & $69.95 \pm 0.452^{\mathrm{c}}$ & $87.74 \pm 0.464^{\mathrm{ab}}$ & $64.91 \pm 1.371$ \\
T3 & $70.58 \pm 0.220^{\mathrm{b}}$ & $87.00 \pm 0.956^{\mathrm{b}}$ & $65.10 \pm 2.173$ \\
T4 & $71.27 \pm 0.376^{\mathrm{ab}}$ & $87.25 \pm 0.417^{\mathrm{ab}}$ & $66.81 \pm 1.499$ \\
\hline
\end{tabular}

Keterangan :

$\mathrm{T} 1=$ Fraksi Tepung Kacang Koro Pedang dengan Perlakuan Perendaman $\mathrm{pH} 4$

T2 = Fraksi Tepung Kacang Koro Pedang dengan Perlakuan Perendaman $\mathrm{pH} 5$

T3 = Fraksi Tepung Kacang Koro Pedang dengan Perlakuan Perendaman pH 6

$\mathrm{T} 4=$ Fraksi Tepung Kacang Koro Pedang dengan Perlakuan Perendaman $\mathrm{pH} 7$

Berdasarkan tabel nilai kecerahan diperoleh hasil fraksi pati tertinggi yaitu $88.07 \%$ pada perlakuan perendaman $\mathrm{pH} 4$ dan fraksi protein memiliki nilai kecerahan terendah sebesar $63.96 \%$ pada perlakuan $\mathrm{pH} 4$ dalam suasana asam. Menurut Asgar dan Musaddad 
(2006), reaksi non enzimatik yang terjadi pada suhu tinggi dengan laju reaksi yang akan meningkat tajam pada suhu yang lebih tinggi sehingga menyebabkan proses pencoklatan semakin cepat. Purwanto et al. (2013) menyatakan bahwa reaksi maillard menyebabkan perubahan warna bubuk menjadi coklat. Nilai kecerahan pati yang tinggi dipengaruhi oleh adanya perendaman asam pada $\mathrm{pH}$ 4. Mutmainah et al. (2013) menyatakan, semakin tinggi konsentrasi asam yang digunakan untuk merendam bahan, maka $\mathrm{pH}$ larutan juga semakin turun sehingga dapat menghambat aktivitas enzim fenolase dikarenakan enzim fenolase tidak dapat bekerja secara maksimal. Hal ini mengakibatkan semakin tinggi pula nilai kecerahan tepung yang dihasilkan.

\section{Aktivitas Air $\left(a_{w}\right)$}

Tabel 3. Aktivitas Air ( $\left.a_{w}\right)$ Fraksi Tepung Kacang Koro Pedang dengan Perlakuan Perendaman $\mathrm{pH}$ yang Berbeda

\begin{tabular}{cccc}
\hline Perlakuan & Fraksi Serat & Fraksi Pati & Fraksi Protein \\
\hline T1 & $0.05 \pm 0.004^{\mathrm{b}}$ & $0.03 \pm 0.005$ & $0.09 \pm 0.008$ \\
T2 & $0.04 \pm 0.003^{\mathrm{b}}$ & $0.03 \pm 0.004$ & $0.09 \pm 0.013$ \\
T3 & $0.04 \pm 0.002^{\mathrm{b}}$ & $0.03 \pm 0.005$ & $0.09 \pm 0.007$ \\
T4 & $0.07 \pm 0.003^{\mathrm{a}}$ & $0.04 \pm 0.007$ & $0.11 \pm 0.027$ \\
\hline
\end{tabular}

Keterangan :

$\mathrm{T} 1=$ Fraksi Tepung Kacang Koro Pedang dengan Perlakuan Perendaman $\mathrm{pH} 4$

T2 = Fraksi Tepung Kacang Koro Pedang dengan Perlakuan Perendaman pH 5

T3 = Fraksi Tepung Kacang Koro Pedang dengan Perlakuan Perendaman pH 6

$\mathrm{T} 4=$ Fraksi Tepung Kacang Koro Pedang dengan Perlakuan Perendaman $\mathrm{pH} 7$

Tabel hasil pengujian nilai $a_{w}$ fraksi tepung kacang koro pedang menunjukkan perlakuan perendaman $\mathrm{pH}$ fraksi serat $\mathrm{T} 4$ berbeda nyata $(\mathrm{P}<0,05)$ dengan perlakuan perendaman $\mathrm{pH} 4, \mathrm{pH} 5$ dan $\mathrm{pH}$ 6, namun tidak memberikan pengaruh nyata terhadap fraksi pati dan fraksi protein. Hasil uji nilai $a_{w}$ fraksi-fraksi tepung kacang koro pedang memiliki nilai yang sangat rendah sehingga dapat menghambat pertumbuhan mikroba di dalamnya. Menurut Richana dan Sunarti (2004), jumlah air dalam bahan akan mempengaruhi daya tahan bahan terhadap kerusakan yang disebabkan oleh mikroba maupun serangga. Pengeringan pada tepung dan pati bertujuan untuk mengurangi jumlah air sampai batas tertentu sehingga pertumbuhan mikroba dan aktivitas enzim penyebab kerusakan pada tepung dan pati dapat dihambat. Perlakuan asam pada saat perendaman juga berpengaruh terhadap tepung yang dihasilkan. Menurut Rosyida dan Sulandari (2014) penambahan asam pada makanan dapat menurunkan $\mathrm{pH}$ sehingga menghambat pertumbuhan mikroba pembusuk.

\section{Densitas Kamba}

Densitas kamba (bulk density) adalah massa partikel yang menempati suatu unit volume tertentu (Gilang et al., 2013). Berdasarkan hasil perhitungan densitas kamba diperoleh hasil rata-rata densitas kamba tepung kacang koro pedang fraksi serat, pati dan protein pada Tabel 4.

Perlakuan perendaman $\mathrm{pH}$ fraksi protein $\mathrm{T} 4$ (perendaman $\mathrm{pH} 7$ ) berbeda nyata $(\mathrm{P}<0,05)$ dengan perlakuan perendaman $\mathrm{pH} 4$ (T1), $\mathrm{pH} 5$ (T2) dan $\mathrm{pH} 6$ (T3). Fraksi serat dan pati tidak menunjukkan perbedaan yang nyata. Besarnya nilai densitas kamba dapat dipengaruhi oleh bentuk maupun ukuran partikel suatu bahan yang berperan dalam penentuan keefektifan dan keefisienan volume ruang yang dibutuhkan untuk ditempati tepung (Widaningrum, 2005). Menurut Handayani et al. (2014) nilai densitas kamba yang kecil akan menempati volume ruang yang lebih besar, ruang pengemasan, penyimpanan dan biaya transportasi yang besar sehingga tidak efektif dalam penyimpanan, hal ini sangat berhubungan dengan ukuran partikel dan kepadatan bahan. 
Tabel 4. Densitas Kamba Fraksi Tepung Kacang Koro Pedang dengan Perlakuan Perendaman $\mathrm{pH}$ yang Berbeda

\begin{tabular}{cccc}
\hline Perlakuan & Fraksi Serat $(\mathrm{g} / \mathrm{ml})$ & Fraksi Pati $(\mathrm{g} / \mathrm{ml})$ & Fraksi Protein $(\mathrm{g} / \mathrm{ml})$ \\
\hline T1 & $0.51 \pm 0.020$ & $0.62 \pm 0.059$ & $0.47 \pm 0.036^{\mathrm{a}}$ \\
T2 & $0.50 \pm 0.017$ & $0.64 \pm 0.027$ & $0.48 \pm 0.048^{\mathrm{a}}$ \\
T3 & $0.49 \pm 0.026$ & $0.63 \pm 0.038$ & $0.47 \pm 0.037^{\mathrm{a}}$ \\
T4 & $0.51 \pm 0.018$ & $0.62 \pm 0.025$ & $0.40 \pm 0.015^{\mathrm{b}}$ \\
\hline
\end{tabular}

Keterangan :

$\mathrm{T} 1=$ Fraksi Tepung Kacang Koro Pedang dengan Perlakuan Perendaman $\mathrm{pH} 4$

T2 = Fraksi Tepung Kacang Koro Pedang dengan Perlakuan Perendaman pH 5

T3 = Fraksi Tepung Kacang Koro Pedang dengan Perlakuan Perendaman pH 6

$\mathrm{T} 4=$ Fraksi Tepung Kacang Koro Pedang dengan Perlakuan Perendaman $\mathrm{pH} 7$

\section{SIMPULAN}

Perlakuan perendaman $\mathrm{pH}$ pada biji kacang koro pedang memberikan pengaruh terhadap kecerahan, nilai $a_{w}$ dan densitas kamba beberapa fraksi, tetapi tidak memberikan pengaruh terhadap nilai rendemen. Secara keseluruhan perlakuan perendaman $\mathrm{pH}$ biji kacang koro pedang tidak menunjukkan pengaruh yang nyata (signifikan) terhadap fraksifraksi tepung secara jumlah tetapi diduga dapat meningkatkan karakter molekul di dalamnya. Perlakuan terbaik dari hasil penelitian adalah dengan perendaman $\mathrm{pH} 7$ karena memiliki nilai rendemen tinggi, meskipun kecerahan dan densitas kamba rendah, karena perlakuan $\mathrm{pH} 7$ tidak mempengaruhi karakteristik fisik hasil tepung kacang koro pedang dan tidak menimbulkan efek residu terhadap hasil akhir karena tidak adanya penambahan asam pada saat perendaman bahan.

\section{DAFTAR PUSTAKA}

Asgar, A dan Musaddad, D. 2006. Optimalisasi cara, suhu dan lama blansing sebelum pengeringan pada wortel. Jurnal Hortikultura 16:3, 245-252.

Gilang, R., Affandi, D.R. dan Ishartani, D. 2013. Karakteristik fisik dan kimia tepung koro pedang (Canavalia ensiformis) dengan variasi perlakuan pendahuluan. Jurnal Teknosains Pangan 2:3, 34-42.

Handayani, N.A., Santosa, H. dan Kusumayanti, H. 2014. Fortifikasi inorganic zink pada tepung ubi jalar ungu sebagai bahan baku bubur bayi instan. Reaktor 15:2, 111-116.

Indriyani, F dan Suyanto, A. 2013. Karakteristik fisik, kimia dan sifat organoleptik tepung beras merah berdasarkan variasi lama pengeringan. Jurnal Pangan dan Gizi 4:8, 23-34.

Indriyani, F., Nurhidajah dan Suyanto, A. 2013. Karakteristik fisik, kimia dan sifat organoleptik tepung beras merah berdasarkan variasi lama pengeringan. Jurnal Pangan dan Gizi 4:8, 27-34.

Istiani, Y. 2010. Karakterisasi Senyawa Bioaktif Isoflavon dan Uji Aktivitas Antioksidan dari Ekstrak Etanol Tempe Berbahan Baku Koro Pedang (Canavalia ensiformis). Tesis. Universitas Sebelas Maret, Surakarta.

Mutmainah, F., Rahadian, D.A.M. dan Amanto, B.S. 2013. Kajian karakteristik fisikokimia tepung sukun (Artocarpus communis) termodifikasi dengan variasi lama perendaman dan konsentrasi asam asetat. Jurnal Teknosains Pangan 2:4, 46-53.

Poernomo, D., Suseno, S.H. dan Wijatmoko, A. 2004. Pemanfaatan asam cuka, jeruk nipis (Citrus aurantifolia) dan belimbing wuluh (Averrhoa bilimbi) untuk mengurangi bau amis petis ikan layang (Decapterus spp.). Buletin Teknologi Hasil Perikanan 8:2, 1118.

Richana, N dan Sunarti, T.C. 2004. Karakterisasi sifat fisikokimia tepung umbi dan tepung pati dari umbi ganyong, suweg, ubi kelapa dan gembili. Jurnal Pascapanen Institut Pertanian Bogor 1:1, 29-37. 
Rizal, S., Sumarlan, S.H. dan Yulianingsih, R. 2013. Pengaruh konsentrasi natrium bisulfit dan suhu pengeringan terhadap sifat fisik-kimia tepung biji nangka (Autocarpus heterophyllus). Jurnal Bioproses Komoditas Tropis 1:2, 1-10.

Rosyida, F dan Sulandari, L. 2014. Pengaruh jumlah gula dan asam sitrat terhadap sifat organoleptik, kadar air dan jumlah mikroba manisan kering siwalan (Borassus flabellifer). E-Journal Boga 3:1, 297- 307.

Widaningrum., Widowati, S. dan Soekarto, S.T. 2005. Pengayakan tepung kedelai pada pembuatan mie dengan bahan baku tepung terigu yang disubstitusi tepung garut. Jurnal Pascapanen 2:1, 41-48.

Widayat, H.P. 2013. Perbaikan mutu bubuk kakao melalui proses ekstraksi lemak dan alkalisasi. Jurnal Teknologi Industri dan Pertanian Indonesia 5:2, 1-10.

Winarno, F.G. 2002. Kimia Pangan dan Gizi. Gramedia Pustaka Utama. Jakarta. 